\title{
THE UPLAND PLOVER AND ITS STATUS IN RELATION TO ENVIRONMENTAL CONDITIONS AND SITUATIONS, PAST AND PRESENT
}

\author{
by G. J. Mitchell, University of Saskatchewan, Regina
}

During the last 100 years many naturalists have observed and shown interest in the Upland Plover (Bartramia longicauda), but until quite recently this interest was mainly concerned with recording distribution, migration phenology and bird numbers. Several detailed investigations during the last 25 years, however, have added materially to our knowledge of Upland Plover biology and ecology and have permitted a better understanding of this species' requirements and the reasons for its general decline in numbers in North America during the early decades of the present century.

\section{Mobility and Size of Home Range}

That the Upland Plover is a highly mobile bird is shown not only in its seasonal migrations, but also in its daily movements during all seasons. Estimates of $\mathrm{migrations}$ approximately 14,000 miles have been made by Beck (1949) for Upland Plovers in Pennsylvania. A review of the many published local bird lists and regional studies in the United States and Canada, and reports by Hudson (1920, 1922), and Wetmore (1926) on Upland Plover wintering areas in Argentina and Uruguay, serve to emphasize the extensiveness of these migrations and provide pertinent information on the distributional and migrational patterns characteristic of this species.

The relationship between the Upland Plover's high mobility and the size of its breeding season home range has been studied by Buss and Hawkins (1939), and Buss (1951) in Wisconsin and the Yukon, respectively. In the Yukon the mobility of the species resulted in large individual breeding ranges where habitats for nest-making, loafing and feeding were provided. Individual home range, although variable, was up to two miles in diameter, and many areas that appeared to have the necessary combinations of habitats were unused because they were too small and did not meet the requirements of these highly mobile birds.

Upland Plover breeding ground requirements include a breeding territory or nesting site which is actively defended by the breeding pair, plus loafing and feeding grounds which are community areas where breeding pairs of Upland Plovers tolerate one another. These pairs do, however, show great variations in their breeding ground requirements and tolerances towards others of their species, and this results in variable plover densities per unit of suitable summer breeding habitat. Breeding pair densities ranging from one pair per 1.5 to 15 acres in Wisconsin, and one pair per 53-106 acres in Pennsylvania, to one pair per 380 acres in the Yukon have been recorded by Buss and Hawkins (1939), Beck (1949) and Buss (1951) respectively. Birds examined in the Yukon averaged lighter in weight than those studied in Wisconsin. suggesting a relatively scarcer food supply on the more northerly grounds. Perhaps the high mobility of Upland Plovers on the northern breeding grounds is a necessary prerequisite for obtaining sufficient amounts of food and conversely, if this species were not extremely mobile on those breeding grounds it could not occupy that range because of food deficiencies.

Although the relationship between mobility and size of winter home range is not well understood, Hudson (1920) reports that the Upland Plover has a wide and uniform distribution over all that portion of the pampas in South America used by these birds in winter. It appears that 
pland Plovers in winter are not mmunal but that each bird requires certain "living space" or range to he exclusion of others.

\section{Habitat Requirements}

The breeding season study made in isconsin showed that Upland Plovers sually built their nests in quack rass (Agropyron repens), blue grass Poa pratensis and $P$. canadensis), nd canary grass (Phalaris sp.) withgrassy hay meadows or tussock astures situated in areas that were bout one-half pasture and one-half orn, small grains and hay. The loafig grounds were areas of pasture ith low tussocks, prairie meadows ith low-growing vegetation, or hay elds with open patches. It was found hat heavy grazing, early grazing, tanding water, or burning and mow$\mathrm{ng}$ caused fields to become unattracive and unacceptable to Upland lovers.

On the Yukon study area five pairs f Upland Plovers nested in a meadow f bluegrass (Poa glauca), pasture age (Artemisia frigida), and anemnes (Anemone sp.) which was surounded by willow (Salix glauca) white spruce (Picea glauca), various hrubs and poplars (Populus tremuides and $P$. balsamifera). Upland lovers also occupied a recently burnd tract of land that had supported solid stand of white spruce 15 years reviously. The dominant successional egetation present during this study vas fireweed (Epilobium angustiolium), weeds, shrubs and grasses nterspersed with spruce, snags and ther debris. Other apparently suitble habitats above timberline were not utilized by plovers early in spring lecause of the presence of snow and ce at these higher elevations at that ime.

Barrows (1912) states that Upland Plovers in Michigan often select nest$\mathrm{ng}$ sites on wet ground, and in such nstances the nests are placed upon he higher and drier portions of the neadow. In Alberta, Rowan (1926) bserved Upland Plover nests in sandy reas that supported only sparse regetation.
Bent (1929) states that the Upland Plover, a characteristic species of the prairies and open grassy fields, began to disappear as the prairies were modified because of agricultural demands. He found that burning of prairie vegetation seriously affected these birds, but noticed that some Upland Plovers appeared to be adapting to new situations and were nesting in cultivated fields containing cereal crops. In Connecticut and Nebraska, Bates (1907) found that Upland Plovers during fall migration were feeding extensively on waste wheat and rye and in Texas, Stevenson (1942) reports that these birds are regularly seen on cultivated lands. Buss and Hawkins (1939) found Upland Plovers nesting in alfalfa and sweet clôver in Wisconsin.

Analysing all these habitat preferences data, it is apparent that the Upland Plover is a bird of the open climax prairie and is closely associated with areas that support short, graminaceous vegetation. The physiognomy of such cover is duplicated cn agricultural lands used as pasture and hay meadows, and these areas too are utilized to some extent by these birds. The two exceptions to this association between Upland Plovers and low-growing grasses are reported by Buss (1951) and Murie (1946) who found these birds using tracts of land which supported an early-successional stage vegetative community of fireweed, shrubs, grasses and forbs in the Yukion, and an association of grasses, sedges and rather tall and scattered willows in Alaska, respectively. Considering the amount of litter and debris on the Yukon area, and the relatively tall aspect of the vegetation on both tracts, these areas were probably sub-optimal for breeding.

More research is necessary to reveal whether it is the shape and height of these short grasses that is attractive to Upland Plovers during the breeding season, or whether the insect fauna associated with this vegetation is the important factor. Inasmuch as plovers often leave nesting areas to 
feed on adjacent sites, it is probably vegetation physiognomy that is significant. In the Yukon study, two adult plovers on a territory with four juveniles were usually located in the shortest grasses, alerted for territorial intrusions by other plovers, or attacks by raptorial birds and only rarely frequented the taller grasses on the territory. It would appear, then, that the height and structure of the vegetational community on the territory is closely related to the value of the area to Upland Plovers. Removing prairie grasses by burning, or reducing grass height by early or heavy grazing or mowing makes otherwise suitable nesting habitat unacceptable. Hudson (1920) states that the removal of large amounts of native, coarse grasses on winter range in Argentina at the turn of the century adversely affected Upland Plovers.

\section{Nesting}

In the Wisconsin study several situations of Upland Plover nest placement and density prevailed. Although nesting territories were usually grouped, this grouping was not consistent from year to year even in similar cover types in the same fields. One year, nest placement strongly suggested a colonial type of nesting. The following year there appeared to be no grouping of nests in this same field. The former situation, where nest density was high, could be construed to represent communal nesting as Buss and Hawkins (1939)) have suggested. Coues (1874) reports that on the prairies the Upland Plovers gather into what almost appears to be colonies.

In the Yukon study, there was no strong evidence that the Upland Plover was a communal or colonial nester. Three pairs of Upland Plovers, nesting near the centre of the study area, left the majority of the area to two other pairs of plovers. Defence of a summer home range did not result in a more or less even amount of ground space per pair as might be expected with other species of ground- nesting birds exhibiting territorial defense.

There appears to be no order or regularity with respect to placement of nests or densities of nests on any one breeding ground in any one year. In some situations Upland Plovers appear to be colonial nesters, whereas in others they are solitary nesters.

Although the reasons for this variation in nest-placement pattern are not clear, one might speculate that the pattern of nest establishment is essentially a complex of small territories crowded upon the available nesting ground. Such a pattern might result in each territory having approximately equal area. It might also be postulated that if an Upland Plover returns to the same breeding ground each year, it might tend to return to precisely the same territory it occupied or began life upon some previous year, and that if there was no significant mortality in the Upland Plover population and if the breeding range size remained constant, the nesting territories would become progressively smaller each year. If mortality did occur to a bird subsequent to its departure from its territory in the fall, this bird's territory the following summer would no longer be inviolate and could, presumably, be occupied by another Upland Plover.

Taking the above considerations one step further, suppose that if the young of any one year are governed by some stimulus to return the following year to the exact territories in which they were hatched, it would conceivably result in local concentrations of "family-line groups" on the breeding range. Being unable to occupy the exact territory, per se, each of these juvenile birds might establish its territory adjacent to the territory it was familiar with the year previous. In fact, each bird might acquire a portion of the territory it knew from the previous year and set up a defensive pattern that would guarantee retention of at least a portion of last year's territory.

Finally, since an appreciable segment of the Upland Plover population 
them for shipment to metropolitan centres and an awaiting market. A marked reduction in Upland Plovers in Minnesota is cited by Roberts (1919) who writes that in the 50-year period after 1870 , plovers were reduced from countless thousands to a point nearing extinction on their summer breeding range. He attributed this population decline to excessive hunting pressures and the existence of a table market for Upland Plovers in the spring.

Bent (1929) also believes that market hunting greatly reduced Upland Plover numbers late in the nineteenth century but he feels that a reduction in summer range habitat was also responsible for these population changes.

In South America, the history of utilization of this bird is similar. Wetmore (1926) and Bent (1929) state that market hunting of Upland Plovers on the winter grounds resulted in drastic population reductions early in the twentieth century.

More recently some authors have recorded increases in Upland Plover numbers and densities at various regions within the summer breeding range. Beck (1949), who recorded a reduction of Upland Plovers from approximately 300 in 1906 to only 15 in 1923 in one region, believes that the plover status on that study area is now stabilized. In New Jersey, Urner and Storer (1949) report that Upland Plovers are increasing in numbers during the fall migrations. Further evidence of local increases of this species has been shown by Terrill (1951) for Ontario.

It can be concluded that prior to the American Civil War, when human densities were relatively low throughout the breeding range of the Upland Plover and there was no widespread and organized market hunting of this species, these birds had presumably reached optimal densities concomitant with existing range conditions. In fact, there were even local increases in Upland Plover densities during this period as a result of land-use changes.
In this regard, Beck (1949) stated that Upland Plovers probably first arrived in some parts of Pennsylvania after the trees were cleared from the broad farm lands. Later in the nineteenth century, market hunting was in vogue and excessive numbers of Upland Plovers were shot for a market demanding a steady supply of these birds for the table.

Radical changes in land-use policy and conversion of much primeval prairie land undoubtedly had an effect on Upland Plover densities. These effects, though probably mostly disadvantageous, may be, at least locally, of benefit to these birds. McAtee and Beal (1912) state that the Upland Plover has a close relationship to agriculture, utilizing as food those insects found on croplands and consuming vegetable foods that are mainly harmful weed seeds.

It appears that market hunting was the major factor responsible for the decline in Upland Plover numbers 'ate in the nineteenth and early in the twentieth centuries. The loss of breeding range also contributed to this marked decrease. The combination of these two factors made heavy inroads on the population of the Upland Plover, a bird species that has been shown by Buss (1951) to have a very low reproductive potential.

The Migratory Birds Convention Act of 1916 put an end to legal, organized market hunting and presumably allowed the population of Upland Plovers slowly to approach a level that is consistent with present day breeding range conditions.

It is to be expected that even more Upland Plover breeding habitat will be destroyed as the conversion of climax prairie to cropland is intensified. On the other hand, some habitat might be created within blocks of climax boreal forest as farm establishment results in the removal of trees and the creation of pasture land. Any trends that exist for Upland Plovers to utilize advantageously the products and by-products of agriculture will most certainly influence the future status of the species. 


\section{REFERENCES}

rrows, W. B. 1912. Michigan Bird Life (quoted by A. C. Bent, 1929).

tes, J. M. 1907. The Bartramian Sandpiper. Bird-lore, $9: 84$

ck, H. H. 1949. Status of the upland plover in Lancaster County, Pennsylvania. Auk, 66 (2) :202-204.

ent, A. C. 1929. Life histories of North American shore birds. U.S. Nat. Mus. Bull. 146.

iss, Irven, O. 1951. The upland plover in southwestern Yukon Territory. Arctic, 4 (3) : 204-213.

iss, Irven, O. and A. S. Hawkins. 1939. The upland plover at Faville Grove, Wisconsin. Wilson Bulletin, 51(4): 202-220.

ues, Elliot. 1874. Birds of the North-West (quoted by A. C. Bent, 1929).

orbush, E. H. 1912. A history of game birds, wild fowl, and shore birds of Massachusetts and adjacent states (quoted by A. C. Bent. 1929).

udson, W. H. 1920. Birds of La Plata (quoted by A. C. Bent, 1929).

udson, W. H. 1922. A hind in Richmond

Park (quoted by A. C. Bent, 1929).
McAtee, W. L. and F. E. L. Beal. 1912. Some common game, aquatic and rapacious birds in relation to man. U.S. Dept. of Agric., Farmer's Bull. 497 (quoted by A. C. Bent, 1929).

Mure, Adolph. 1946. Observations on the birds of Mount McKinley National Park, Alaska. The Condor, 48(6): 253-261.

Roberts, T. S. 1919. Water birds of Minnesota past and present. Biennial Rep. of the State Game and Fish Comm. of Minn., for the Biennial Period ending July 31, 1918 (quoted by A. C. Bent, 1929).

Rowan, William. 1926. Notes on Alberta waders included in the British list. Brit. $h$ Birds, $20: 2-10,34-42,82-90,138-145,186-192$ (quoted by A. C. Bent, 1929).

Stevenson, J. O. 1942. Birds of the central panhandle of Texas. The Condor, 44(3):108115.

Terrill, L. McI. 1951. Shorebird migration at Montreal. Can. Field Nat., 65(3):87-98.

Urner, C. A. and R. W. Storer. 1949. The distribution and abundance of shorebirds on the north and central New Jersey coast, 19281938. Auk, 66 (2):177-194.

Wetmore, Alexander. 1926. Observations on the birds of Argentina, Paraguay, Uruguay, and Chile. U.S. Nat. Mus. Bull. 133 (quoted by A. C. Bent, 1929).

\section{NOTES ON THE BREEDING BIOLOGY OF THE MARSH HAWK IN ALBERTA AND SASKATCHEWAN}

\section{by Spencer G. Sealy, Department of Zoology, U.B.C., Vancouver}

This study of the breeding biology $f$ the Marsh Hawk, Circus cyaneus Linnaeus), was carried out in Alerta and Saskatchewan during the ummers of 1959 to 1964. Four sumhers were spent in the Battleford rea of northwest central Saskatchetan and two in the Brooks area of outheastern Alberta. The Battleford rea $\left(52^{\prime} \mathrm{N}, 108^{\prime} \mathrm{W}\right)$ is situated in he forest and grassland portion of he Boreal Forest Region (Rowe, 959); the Brooks area $\left(50^{\prime} \mathrm{N}, 111^{\prime}\right.$ V) is situated in the Grassland Reion (Rowe, op. cit.). The two areas re roughly 250 miles apart (see igure 1). A total of 32 nests was tudied and a discussion of nest-buildng, eggs, egg-laying and incubation, and young and their development is resented.

The Battleford area consists of unlulating, grass - covered hills interpersed with groves of aspen (Populus remuloides) on a level above the
North Saskatchewan and Battle rivers, the northern boundary of the area under consideration. Approximately 35 percent of the area was under cultivation at the time of this study, the remaining portion being tree-covered or pastureland. Aspen stands grow in small to large groves at intermittent spots on hillsides and in valleys; in other locations along the North Saskatchewan and Battle rivers balsam poplar ( $P$. balsamifera), white birch (Betula papyrifera), willow (Salix spp.), saskatoon (Amelanchier) and hawthorne (Crataegus) are also prevalent species. No natural coniferous growth is present although a few planted stands serve as shelterbelts on some farms. Patches of rose (Rosa) and snowberry (Symphoricarpus), locally known as "buckbrush", are numerous between the tree groves.

The Brooks area, which is situated in the Eastern Irrigation District 